\title{
The Roles and Sustainability of Local Institutions of Mangrove Management in Pahawang Island
}

\author{
Indra Gumay Febryano $^{1 *}$, Didik Suharjito ${ }^{2}$, Dudung Darusman ${ }^{2}$ \\ Cecep Kusmana ${ }^{3}$, Aceng Hidayat ${ }^{4}$
}

\begin{abstract}
${ }^{1}$ Graduate School of Bogor Agricultural University, Dramaga Main Road, Campus IPB Dramaga, Bogor, Indonesia 16680
${ }^{2}$ Department of Forest Management, Faculty of Forestry, Bogor Agricultural University, Academic Ring Road, Campus IPB Dramaga, PO Box 168, Bogor, Indonesia 16680

${ }^{3}$ Department of Silviculture, Faculty of Forestry, Bogor Agricultural University, Academic Ring Road, Campus IPB Dramaga, PO Box 168, Bogor, Indonesia 16680

${ }^{4}$ Department of Resource and Environmental Economics, Faculty of Economics and Management, Bogor Agricultural University, Academic Ring Road, Campus IPB Dramaga, PO Box 168, Bogor, Indonesia 16680
\end{abstract}

\section{Received March 19, 2014/Accepted July 14, 2014}

\begin{abstract}
Local institutions along with community participation are crucial things in a sustainable development. Collective actions performed by a community in managing natural resources have led to success, but local institutions are also facing challenges to institutional sustainability. This research aimed to elucidate and explain the roles and sustainability of local institutions of mangrove management. This research is a qualitative research, using a case study method Research results showed that the majority of community support and admit that mangroves in their region as Mangrove Preservation Area under controlled by management of local organization with agreed rules. Nevertheless, the inability of local organizations to enforce such rules when facing investors and politics in the local level has caused these organizations to elude their support and institutional status. It is for this reason that local institutions need to be strengthened through collaboration among local institutions, local, national and international NGOs, universities, research institutions, and many others. Such collaboration can improve bargaining position of local institutions, so that finally can promote regency government policies which favoring more to local institutions. Mangrove management in a sustainable way by local institutions will help regency government in rural development.
\end{abstract}

Keywords: local institution, organization, institution, community, mangrove

Correspondence author,e-mail: indragumay@yahoo.com,tel.: +62-81369050731

\section{Introduction}

Local institutions along with community participation are things that need to be taken into consideration in sustainable development (Uphoff 1992). The importance of both institutions and local organizations in rural development has been widely admitted and become a part of development policies in many countries (Fisher 2004). The reason is people know each other in a community level and they can create opportunities to carry out collective actions and mutual assistance as well as to mobilize and manage resources independently (Uphoff 1986). Furthermore, community-based management can turn unsustainable practices into more sustainable ones through a number of ways, such as self-organization, institutional development, experiment, knowledge elaboration, and social learning (Marschke \& Berkes 2005).

Community participation has to be given major attention by policy makers, because the success of local institutions in the long run will not be definite without such participation. Kamoto et al. (2013) argued that weak government policies and does not enough consider local institution complexity, as well as limited involvement of community and local institutions in the formulation and implementation of policies can create and strengthen practices of destructive resource utilization and social conflicts. However, Tole (2010) pointed out that weak capacity of state and community can be strengthened through external support of non-government agents, including NGOs, donor institutions, and charity organizations, although most support has relatively limited scopes and last for only a short period.

The contribution of local institutions in managing natural resources has also appeared in mangrove management. In general, implementation of knowledge and traditional practices have supported the better performance of community-based mangrove management (Maconachie et al. 2008). Lots of achievements in mangrove conservation are able to gain when local institutions are supported by government structure, national policies and regulations (Egbuche et al. 2009).

Uphoff (1994) pointed out that capacity building in local level includes establishment and strengthening of local institutions. Local institution strengthening is extremely 
essential since local institutions have obtained neither status nor institution quality as a result of their achievement and appreciation from community. Accordingly, majority of local institutions are viewed more as organizations rather than institutions. Organization strengthening, however, has to be focused on the roles and process of decision making, resource mobilization and management, communication and coordination, as well as conflict resolution. When these functions are carried out effectively, the organization will build support, loyality and commitment, enabling organization to function more effectively so that it will improve its institutional status. Uphoff(1986) paid attention to organization category which takes the form of an institution or the opposite. An organization is defined as the structure of recognized and accepted roles; while an institution is a complex of norms and behaviors that persists overtime by serving some socially valued purposes.

Research on local institutions of mangrove management is crucial because collective actions performed by community have encountered lots of success, but local institutions are also facing challenges to institutional sustainability. This research, therefore, is aimed to outline and explain the roles and sustainability of local institutions of mangrove management. It is believed that knowledge and understanding on this matter will be beneficial for any related parties in making equitable, prosperous and sustainable mangrove management recommendations, so that mangrove can be conserved and offer advantages for all sides.

\section{Methods}

Research was carried out from January to June 2013 in Pahawang Island, one of the small islands in Lampung Bay. Geographically, Pahawang Island is located in $\mathrm{S}^{\circ} 40.2^{\prime}-5^{\circ} 43.2^{\prime}$ and $105^{\circ} 12.2^{\prime}-\mathrm{E} 105^{\circ} 15.2^{\prime}$, covering a total area of $1,046.87$ ha (Rizani 2007). Administratively, this island belongs to the region in Marga Punduh District, Pesawaran Regency, Lampung Province, Indonesia. Pahawang Island is a village that divided into several subvillages; namely: Suak Buah, Penggetahan, Jaralangan, Kalangan, Cukuh Nyai, and Pahawang. Based on the participatory mapping in 2006, the total area of mangroves in Pahawang Island reached 141.94 ha (Rizani 2007).

This research was a qualitative research, using a case study method. Data were collected in several ways, consist of indepth interview, participant observation and document analysis. Interviews involved $35 \mathrm{key}$ informants. Collected data were analyzed regarding their organizations and institutions (Uphoff 1986; 1994). The former were examined from their rules and role structure of mangrove management organization; while the latter were measured from the levels of understanding, obedience, and trust towards existing mangrove management rules.

\section{Results and Discussion}

Establishment and strengthening of local institutions Local community used mangroves to fulfill their daily needs, such as for building materials and firewoods. Such utilization, however, is mostly conducted in an unsustainable way, for instance, by cutting trees unselectively or cutting trees in its base that causes mangroves to die. The conversion of mangrove area into ponds and the removal of worms living in mangroves' roots, moreover, worsen the condition of mangrove in that certain area. Ponds construction for tiger prawn and milkfish in Jaralangan Subvillage and Kalangan Subvillage started in 1980s. Due to the decline of ponds land quality and limited capital, those ponds were left by their owners and not used for relatively long time. Worms removal activities have been conducted by people outside the village since 2003. This activity led to the death of mangroves as its roots were cut to make the worms removal easier. Worms were then purchased by middlemen with relatively high price to be resold to shrimp hatchery companies in Lampung Province as shrimp fry feed. Rizani (2007) pointed out that mangroves cutting was conducted extensively by a foreign company from Taiwan, clearing away 12 ha in Suak Buah Subvillage and 6 ha in Jaralangan Subvillage in 1975, as well as making use of the local community as their labor. In addition, the cutting of mangroves for charcoal and building material without any permission from local government was also carried out by people from Java Island in 1984 who also purchased mangroves cut by local community.

Mangrove exploitation disregarding conservation rules creates negative impacts on both environment and community. Mangrove degradation leads to abration, sea water instrusion, and the disappearance of natural protection towards violent crashing wind and sea waves. Mangrove degradation also results in the decrease of various kinds of fish and sea biota, and many other fauna. The most dreadful impact experienced by community, particularly those relying their lives as fishermen, is the difficulty in obtaining the catch, such as fish, crab, shrimp, squid, and the like. The number of small shrimp, used as fish bait, also declined drastically. Because of such mangrove degradation and its unmanageable impacts, fishermen turned to find job in land as waged labors. Another impact is that timbers for building materials and firewoods used to fulfill community's daily needs became less. Mangroves, indeed, has crucial functions and benefits to support lives (Bosire et al. 2008; Nagelkerken et al. 2008; Walters et al. 2008) in a small island like Pahawang.

Due to mangrove degradation and its alarming impacts in Pahawang Island, Mitra Bentala NGO has made efforts to facilitate community to conserve mangroves in their village since 1997. Facilitation was emphasized more on cooperative learning to overcome various problems regarding unsustainable mangroves resource utilization. Informant revealed that:

"Number of ways were conducted by involving community leaders, not only in the formal but also informal sectors, in order to build understanding towards the existing problems. The process was initiated by giving understanding and building belief on equality in mangroves utilization. This problem was discussed from person to person, from one subvillage to another, making it a hot issue in the village level. Thus, efforts to conserve mangroves existence finally became immense needs in community level. The process to make people appreciate the importance of mangroves became incredibly 
effective, when such understanding gradually turned into awareness. Such community awareness is then implemented in daily behavior in terms of active participation and real actions to manage mangroves in a sustainable way".

In 2005, the community and Mitra Bentala NGO held a workshop on mangrove management and thus establishing an agreement to conserve mangroves. One year later, in 2006, community along with Mitra Bentala NGO (in cooperation with The European Commissions and UNDP) were succeed in urging local government to issue Village Rules, Number 02/007/Perdes-phm/XI/2006 on Mangrove Forest Conservation. As a follow up action the Decree of the Head of Village, Number 03/007/KD-DPM/11.1/2006 Mangrove Conservation Area Rules was also issued. To realize and enforce those agreed rules, Mangrove Conservation Area Management Board (Badan Pengelola Daerah Perlindungan Mangrove/BPDPM) was established based on the Decree of the Head of Village, Number 04/007/KD-BPDPM/11.2/2006. A study conducted by Datta et al. (2012) showed that the success of community-based mangrove management was performed by restructuring institutions supporting subsistent-based users, thus, ensuring community participation in making decision and in utilizing mangroves resources. Shah and Jussof (2007) in their study in Pakistan coastal area revealed that facilitation from WWF Pakistan and local NGOs are able to increase local community capacity in mangrove conservation that ensure the continuity of community lives as fishermen.

Refers to Uphoff (1986) regarding to definition of organization and institution, BPDPM and Mangrove Conservation Area Rules are local institutions that autonomously given authority by village government to manage mangroves in Pahawang Island. The structure and roles of BPDPM are shown in Figure 1. The Mangrove Conservation Area Rules divide mangrove in Pahawang Island into several zones (Figure 2), containing obligation, permissive, and forbidden conducts, and sanctions to be applied gradually. A number of important matters existing in those rules are as following:

1 Mangrove Conservation Area is divided into 3 zones; namely, core, buffer, and utilization. Suak Buah Subvillage is the basis of Mangrove Conservation Area as it has all zones covering a total land of approximately 30 ha; while Penggetahan Subvillage, Jeralangan Subvillage, and Kalangan Subvillage belong to utilization zone only.

2 Obligations and permissive conducts in Mangrove Conservation Area are: (a) every villager has to guard, watch, and maintain the sustainability of Mangrove Conservation Area, (b) every villager and/or groups have the rights and responsibility to take active parts in planning and managing environment in conservation areas, (c) any group or person who are going to carry out any activity in Mangrove Conservation Area has to report and obtain permission from management board, and (d) activities allowed to do in the core zone are limited to research, tour, and education, after reporting and obtaining pemission from management board and paying fee for monitoring and maintainance.

3 Things forbidden to perform in the core zone are: (a) trespassing/passing/crossing the core zone, except for emergency, (b) cutting, burning, gathering firewoods, removing worms, removing mangroves bark, (c) fishing/catching fish with any kind of fishing gear, (d) taking plant and animal biota, alive or dead, (e) throwing an anchor in core zone, (f) growing seaweed and raising fish surrounding core zone, (g) placing lift net surrounding core zone, (h) throwing garbage surrounding core zone, and (i) conducting mining surrounding core zone. Finding small shrimp as fisherman's fish bait is still allowed to do in the core zone, as long as it is not too much and detected by management board.

4 Things prohibited in supporting buffer zone: (a) taking both plants and animals with any equipment: traditionally or modern, (b) hunting animals, (c) taking plant and animal biota, alive or dead, (d) light fishing intentionally, (e) throwing garbage, and (f) conducting mining.

5 Things prohibited to do in utilization zone, are: (a) cutting trees in its base, (b) digging for worms, (c) throwing nonorganic garbage, (d) cutting trees unselectively, (e) removing mangroves stand, and (f) conducting destructive activities both in land and in the sea. All activities conducted in this zone is only limited to those to fulfill household needs, with the permission of management board and village personnels.

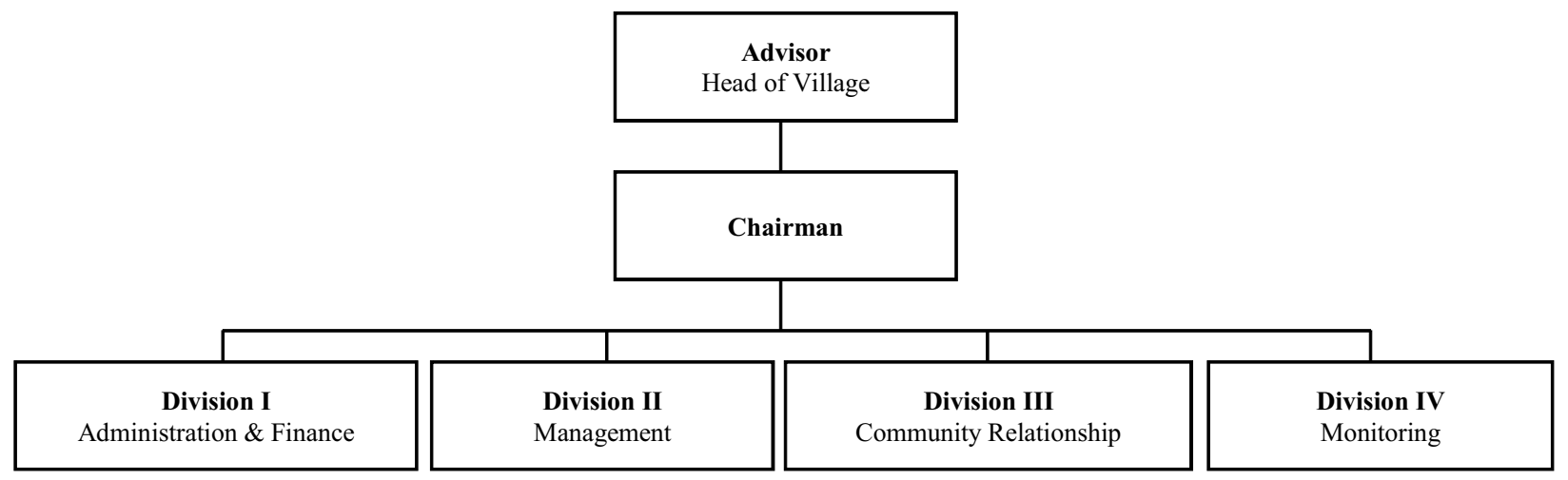

Figure 1 Structure and roles of BPDPM organization. 


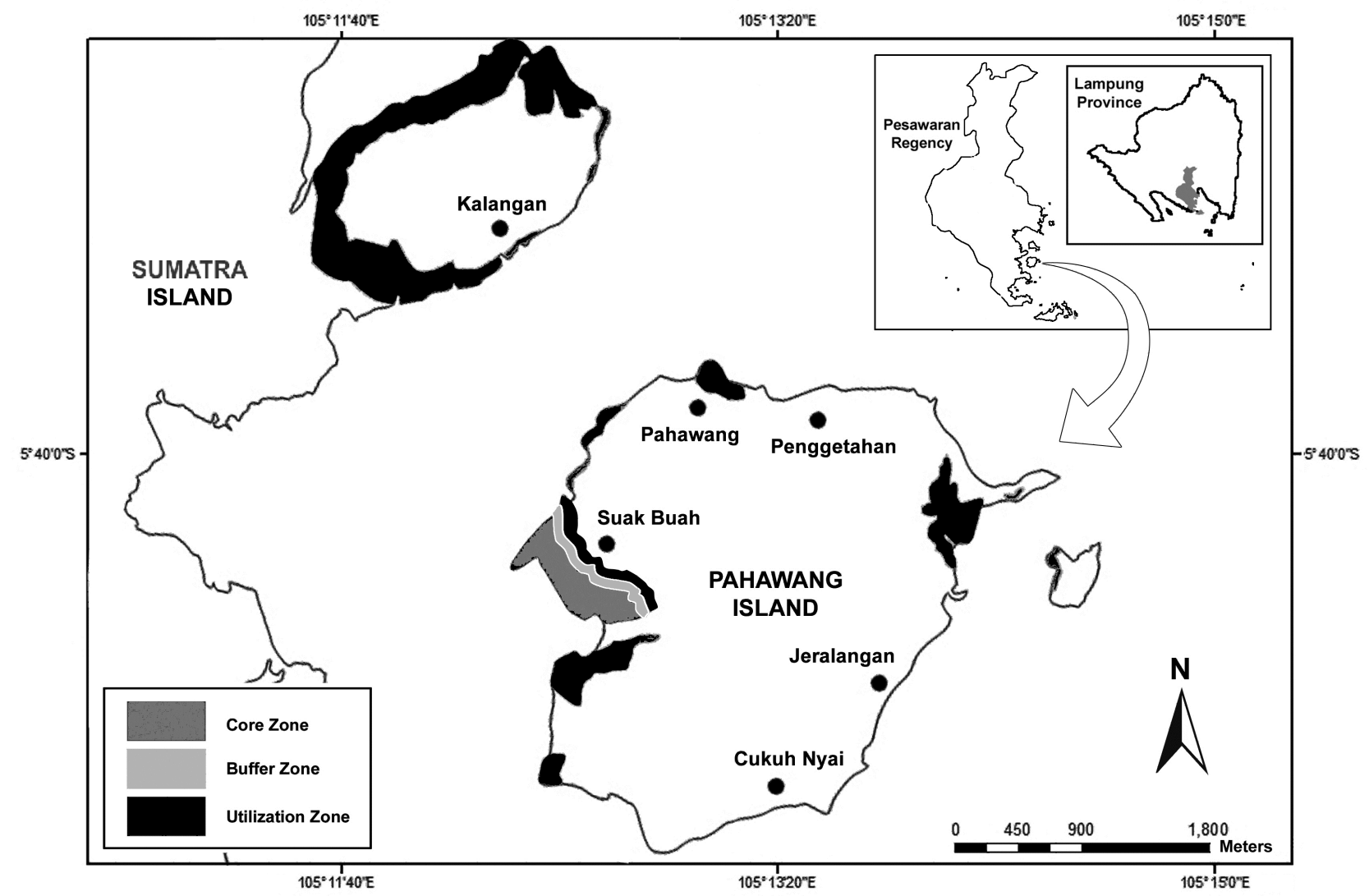

Figure 2 Mangrove conservation area in Pahawang Island.

6 Sanctions applied upon the above rules violation: (a) first level sanction, violators have to ask for apology, return all they obtained from Mangrove Conservation Area, and sign a letter of declaration stating that they will never conduct the violation in front of village personnels, management board, and community, (b) second level sanctions, given to those intentionally breaking the rules for the second time, include paying a fine of IDR25,000,000 (about USD2,175) and giving away all of the equipment used in such rule violation of Mangrove Conservation Area, (c) the third sanction level is given to those intentionally breaking the rules for the third time, covering a fine of IDR50,000,000 (about USD4,350), giving away all of the equipment used in such rule violation of Mangrove Conservation Area, obligation to conduct social work for community (such as community work, fixing structure or infrastructure like places for bathing, washing and toilet, and many others) or other sanctions to be determined by management board, and reforesting the damage, and (d) for those intentionally breaking the rules for more than three times, the third level sanction will be given, then they were handled over to police officers as investigating officer, to be further processed in line with the existing rules and laws.

Strengthening local institutions in sustainable mangrove management is carried out by capacity building of both community and BPDPM. These efforts are facilitated by Mitra Bentala NGO through a number of training activities in cooperation with donor institutions, both nationally and internationally. Capacity building can be viewed from the increase of knowledge, skills, and attitudes of community and BPDPM. Informant revealed that:

"At the beginning, we don't care about mangrove in our village. After Mitra (Mitra Bentala NGO) came to our village, we realized how important mangrove for us. Moreover, people felt the impact of abrasion and were difficult to catch fish and shrimp. How can we catch the fish if the shrimp used for bait is getting hard to find? Whereas shrimp usually live in mangrove. It will destroy us if it is allowed to be continued. If not us, the people who live here, who else cares? If we still want our children and grandchildren live in ease, we have to change. It doesn't mean that the mangrove cannot be used. BPDM still gives the people flexibility to take product from mangrove, but the amount is limited only for meet the people needs. But they should not take it for business purposes, it is only for personal need".

Community involvement in mangrove nursery and ecotourism was another indication of community capacity building. It aims to develop strong support upon sustainable mangrove management and improve the means of livelihood of local community so as to reduce pressure on mangroves. Badola et al. (2012) and Wilkinson and Salvat (2012) explained that community capacity building can be conducted by improving their awareness and better education regarding the causes of degradation and their possible solusion as well as aids to develop sustainable means of livelihood alternatives. Futhermore, Suharjito 
(2009) pointed out that crisis on environment and poverty urge ideas to increase the role of local community that can only be solved through status realization and local community roles in the development.

Capacity building of BPDPM urged BPDPM to develop wider networking and to take active participation in building mangrove redemption agreement in the coastal area of Pesawaran Regency. These activities were carried out in cooperation with Mitra Bentala NGO, heads of the village, and community leaders in 2010. Recommendations were used as policy negotiation matter proposed to regency government to induce the regulation on mangrove management. Together with Mitra Bentala NGO, BPDPM played a part in facilitating the establishment and guidance of mangrove management organizations in several surrounding villages. In addition, BPDPM was often invited as resource person in various activities related to sustainable mangrove management, within or outside Lampung Province. Vandergeest (2007) showed how the concerns of the environmental and social impacts of mangrove conversion in Thailand has promoted the establishment of networking that oriented to social and ecological relationships as a way to bring together a variety of motives, including commercial interests, environmental concerns, economic growth, and community welfare.

Acknowledgment towards BPDPM performance in mangrove management was attained from provincial government in 2010, when the chairman of BPDPM was granted the Kalpataru Award under the category of environment saver. Such a reward presentation is, indeed, recognition of the government showing that local initiative and participation is able to manage natural resources, particularly mangrove, in a sustainable way. The study carried out by Meilasari-Sugiana (2012) in South Sulawesi Province, Indonesia, revealed that when the relationship between social environment and nature is admitted, it will support the existence of reflective capacity to protect mangroves collectively. Likewise, the other study in South Sulawesi Province, Indonesia (Amri 2005) and in Bangladesh (Roy et al. 2013) showed that participation and mangrove management can be urged by providing mangrove property rights for the community.

Sustainability of local institutions Development of mangrove management in Pahawang Island was strongly associated with the dynamics that occured in the community (Figure 3). Development of mangrove management in Pahawang Island was strongly associated with the dynamics that occured in the community (Figure 3 ). The position of local institutions began to grow strong and institutionalized since the establishment of BPDPM and Mangrove Conservation Area Rules in 2006 until 2010. This was due to community facilitation on mangrove management carried out by Mitra Bentala NGO since 1997 and community trust towards the performance of BPDPM. The high trust, understanding, and obedience in mangrove conservation can be seen from the support and active participation of community on the rules agreed upon in managing Mangrove Conservation Area. Informant revealed that:

"When BPDM and Mangrove Conservation Area Rules issued, there was still people who arbitrarily cutting down mangroves. In their view, mangroves belong to nobody, so it is free to cut down. They said, 'What were the advantages prohibit us? Were you paid for our food?'.

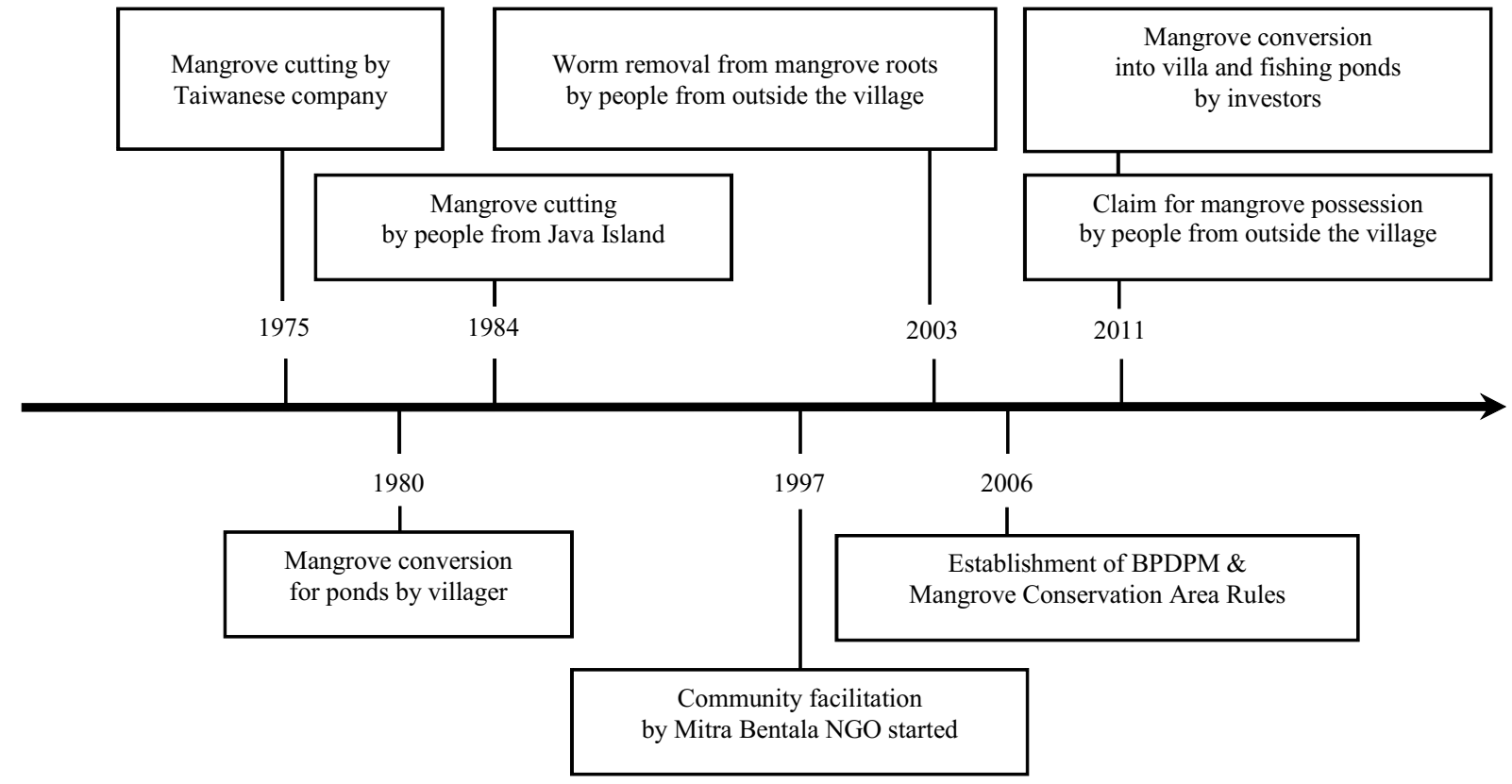

Note: - Pahawang Island has been inhibited since 1920

- Mangrove area based on participatory mapping in 2006 was 141.94 ha

Figure 3 Development of mangrove management in Pahawang Island. 
I said there wasn't a material benefit for me. I wasn't paid, no facility, but we have to think what will happen with our life if this mangroves vanish? I explained it to them slowly, it made them realized and started to follow the rules to conserve the mangroves. BPDPM and community were also able to prevent people from surrounding village who want to take mangroves timbers or worms surrounding mangroves roots, and unilateral claim on mangrove possession in our village".

According to Jones et al. (2011) the effectiveness of local institutions in managing natural resources and the possibility of developing strong collaborations in the community of Agiasos, Greece associated with high trust to local institutions. Pfahl (2005) explained that institutional sustainability referred to institution competence in coordinating human interactions in order to facilitate decision making and carry out sustainable policy.

Nevertheless, local institutions become weak since they cannot prevent the conversion and unilateral claim on mangrove possession by investors who were also government officials in 2011. Mangrove conversion into villa and fishing ponds by using heavy equipment was carried out in utilization zone, very close to the basis of Mangrove Conservation Area at Suak Buah Subvillage. The beauty of the beach in Pahawang Island invited the interest of investors who had very strong access like businessman or government officials. The low income in agricultural and fishery made ccmmunity's position susceptible economically. As a result, lozal people finally cannot avoid selling their land that lozated near the beach or mangroves. This made the pcitentiality for converting mangroves increase as investors ccnsidered that mangroves next to their land belong to them. Primavera and Esteban (2008) showed institutions and political actions were so weak that made mangroves areas occupied by illegal shrimp ponds were not able to be handled over by mangrove community-based management initiatives in the Phillipines.

Such condition became worse because the head of village was an advisor in BPDPM and some village government officer also BPDPM officer. This caused them unable to differentiate between village policy and BPDPM policy. As a consequence, BPDPM was not independent anymore, and its movement became weak. BPDPM as a community organization was supposed to be independent and not interfered by government policy that obviously did not support mangrove management, such as policy that gave no limitation to mangrove conversion by investors. An excessive dominant government will weaken local institutions since local institutions cannot be parted from government intervention. BPDPM did not obtain any support from the village government-an extremely distinct attitude when BPDPM was established in 2006. Moreover, the rules more difficult to be enforced when the chairman of BPDPM was employed by investors as the security personnel in that particular project. Informant revealed that:

"It was hard, because he is government official. Who dares him? Moreover BPDM did not get support from the village government, unlike when they built it. I was also hired as a security in the project. Now I am so completely wrong, I only can let the projects leaders know that mangroves should not be converted, but the project still goes on",

It turned out that the networking developed by Mitra Bentala NGO and BPDPM was not able to avert the mangrove conversion by investor. Saunders et al. (2008) revealed that politics in community level played the role in destroying community-based mangrove management and devastating the trust built in Tanzania.

Such indecisive attitude shown by BPDPM in enforcing the rules of Mangrove Conservation Area when facing investors and politics in local level caused community trust decline drastically; as a result some people started to disobey the existing rules. They began to cut mangroves for building materials and firewoods unselectively or cut it in its base which lead mangrove to die. Other parts of community even produced charcoals commercially, using mangroves as its raw materials. Informant revealed that:

"Why make rules? Government officials are permitted, but we are not. We also deserve the right and we did just for the necessities of our life. It is different to the government officials. He destroys the entire mangrove, but BPDM can do nothing".

BPDPM faced a dilemma in enforcing its rules and only to make informal approach to the community to warn their disobedience and requested them not to break the rules. Informant revealed that:

"I probably cannot apply the rule, let alone go to the police. I don't ferl comfortable, I can only scolds amicably. This island is small, so we know each other well and most of the m are my family".

Furthermore this gave an impact on sustainability of its institution and mangroves resources. Refers to Uphoff (1994), wher BPDPM failed to fulfill the needs and hopes of the community towards sustainable mangrove management, particularly when facing conflict of mangrove conversion, the organization lost its support and institutional status.

\section{Conclusion}

Local institutions play a crucial role in mangrove management, when community take active participation in implementing the rules under management of local organization. Community initiative and participation can mobilize and organize them to carry out collective actions in sustainable mangrove management. However, politics in the local level have declined community trust towards institutional support and status of local organization. The local institution need to be strengthened through collaboration among local institutions, local, national and international NGOs, universities, research institutions, and many others. Such collaborations cannot be carried out in cooperation with government since the government officials are parts of the investors which can affect politics in the local level. Collaboration is expected to be able to support the bargaining position of local institutions, so that they can urge regency government to be inclined more to the local institutions. Success of local institutions in managing mangroves resources in a sustainable way will, indeed, help regency government in rural development throughout its coastal area. 


\section{Acknowledgements}

The authors wish to sincerely acknowledge Indonesia's Ministry of Education and Culture who funded the study.

\section{References}

Amri A. 2005. Community participation in rehabilitation, conservation and management of mangroves: lessons from coastal areas of South Sulawesi, Indonesia. African Study Monographs, Supplement 29:19-30.

Badola R, Barthwal S, Hussain SA. 2012. Attitudes of local communities towards conservation of mangrove forests: a case study from the east coast of India. Estuarine, Coastal and Shelf Science 96:188-196. http://dx.doi.org/ 10.1016/j.ecss.2011.11.016.

Bosire JO et al. 2008. Functionality of restored mangroves: a review. Aquatic Botany 89:251-259. http://dx.doi.org/ 10.1016/j.aquabot.2008.03.010.

Datta D, Chattopadhyay RN, Guha P. 2012. Community based mangrove management: a review on status and sustainability. Journal of Environmental Management 107:84-95.http://dx.doi.org/10.1016/j.jenvman.2012.04 .013 .

Egbuche CT, Zhang J, Ukaga O. 2009. Community-based natural resources management (CBNRM) in Xinhui, Guangdong Province, China. Environment, Development and Sustainabiliy 11:905-928. http://dx.doi.org/10.1007/s10668-008-9160-5.

Fisher RJ. 2004. What makes effective local organizations and institutions in natural resource management and rural development. In: Proceedings of Role of Local Communities and Institutions in Integrated Rural Development Seminar; Teheran, June 15-20, 2002. Pp. 85-96.

Jones N, Gleridou C, Dimitrakopoulos PG, Evangelinos KI. 2011. Investigating social acceptability for public forest management policies as a function of social factors. Forest Policy and Economics 14(1):148-155. http://dx.doi.org/10.1016/j.forpol.2011.07.015.

Kamoto J, Clarkson G, Dorward P, Shepherd D. 2013. Doing more harm than good? Community based natural resource management and the neglect of local institutions in policy development. Land Use Policy 35:293-301. http://dx.doi.org/10.1016/j.landusepol.2013.06.002.

Maconachie R, Dixon AB, Wood A. 2008. Decentralization and local institutional arrangements for wetland management in Ethiopia and Sierra Leone. Applied Geography 29(2):269-279. http://dx.doi.org/10.1016/j. apgeog.2008.08.003.

Marschke M, Berkes F. 2005. Local level sustainability planning for livelihoods: a Cambodian experience. International Journal of Sustainable Development and
World Ecology 12:21-33. http://dx.doi.org/10.1080/ 13504500509469615.

Meilasari-Sugiana A. 2012. Collective action and ecological sensibility for sustainable mangrove governance in Indonesia: challenges and opportunities. Journal of Political Ecology 19:184-201.

Nagelkerken I et al. 2008. The habitat function of mangroves for terrestrial and marine fauna: a review. Aquatic Botany 89:155-185. http://dx.doi.org/10.1016/ j.aquabot.2007.12.007.

Pfahl S. 2005. Institutional sustainability. International Journal of Sustainable Development 8(1-2):80-96. http://dx.doi.org/10.1504/IJSD.2005.007376.

Primavera JH, Esteban EJMA. 2008. A review of mangrove rehabilitation in the Philippines: successes, failures and future prospects. Wetlands Ecology and Management 16(5):345-358. http://dx.doi.org/10.1007/s11273-0089101-y.

Rizani. 2007. Menanam Pohon Kehidupan di Pulau Pahawang. In: Afiff S, Zakaria RY, editors. Hutan dan Manusia: Mendorong Pengelolaan Hutan oleh Rakyat. Yogyakarta: Karsa and SGP PTF UNDP-EC-SEAMEO SEARCA.

Roy AKD, Khorshed Alam K, Gow J. 2013. Community perceptions of state forest ownership and management: a case study of the Sundarbans mangrove forest in Bangladesh. Journal of Environmental Management 117:141-149. http://dx.doi.org/10.1016/j.jenvman. 2012.12.004.

Saunders F, Mohammed SM, Jiddawi N, Sjoling S. 2008. An examination of governance arrangements at Kisakasaka mangrove reserve in Zanzibar. Environmental Management 4:663-675. http://dx.doi. org/10.1007/s00267-007-9050-x.

Shah AA, Jusoff K. 2007. Mangrove conservation through community participation in Pakistan: The case of Sonmiani Bay. International Journal of Systems Applications, Engineering \& Development 4(1):75-81.

Suharjito D. 2009. Devolution of forest management in Indonesia: Comparison between Indonesia and Philipina. Jurnal Manajemen Hutan Tropika 15(3):123-130.

Tole L. 2010. Reforms from the ground up: a review of community-based forest management in tropical developing countries. Environmental Management 45:1312-1331. http://dx.doi.org/10.1007/s00267-0109489-Z.

Uphoff N. 1986. Local Institutional Development: An Analitical Sourcebook with Cases. Connecticut: Kumarian Press. 
Uphoff N. 1992. Local Institutions and Participation for Sustainable Development, Gatekeeper Series No. 31. London: International Institute for Environment and Development.

Uphoff N. 1994. Revisiting Institution Building: How Organizations Become Institutions. In: Uphoff N, editor. Puzzles of Productivity in Public Organizations. San Francisco: Institute of Contemporary Studies Press.

Vandergeest P. 2007. Certification and communities: Alternatives for regulating the environmental and social impacts of shrimp farming. World Development
35(7):1152-1171. http://dx.doi.org/10.1016/j.worlddev. 2006.12.002.

Walters BB et al. 2008. Ethnobiology, socio-economics and management of mangrove forests: a review. Aquatic Botany 89:220-236. http://dx.doi.org/10.1016/j. aquabot.2008.02.009.

Wilkinson C, Salvat B. 2012. Coastal resource degradation in the tropics: does the tragedy of the commons apply for coral reefs, mangrove forests and seagrass beds. Marine Pollution Bulletin 64:1096-1105. http://dx.doi.org/10. 1016/j.marpolbul.2012.01.041. 